\title{
Reclaimed Wastewater Irrigation and Fertilization of Mature 'Redblush' Grapefruit Trees on Spodosols in Florida
}

\author{
Michael A. Maurer and Frederick S. Davies \\ Horticultural Sciences Department, University of Florida, P. O. Box 110690, Gainesville, FL 32611 \\ Donald A. Graetz \\ Soil and Water Science Department, University of Florida, P. O. Box 110290, Gainesville, FL 32611 \\ Additional index words. Citrus paradisi, effluent, nutrition
}

\begin{abstract}
An experiment was designed to determine the effects of canal water and reclaimed wastewater on growth, yield, and fruit quality of mature (25-year-old) 'Redblush' grapefruit (Citrus paradisi Macf.) trees on sour orange (C. aurantium L.) rootstock. The study was conducted from 1 Oct. 1990 to 18 Apr. 1994 at a site adjacent to the Indian River County municipal wastewater treatment facility located near Vero Beach, Fla. Treatments included canal water applied based on one-third or two-thirds soil water depletion and reclaimed wastewater applied using microsprinklers at $23.1 \mathrm{~mm} / \mathrm{week}$ (low), $30.7 \mathrm{~mm} /$ week (moderate) and $38.6 \mathrm{~mm} /$ week (high). Trees receiving low and moderate levels of reclaimed wastewater had the largest canopies and trunk diameters and highest yields, even though the amount of fertilizer applied was less than that of canal water plots. Leaf nutrient levels were generally within acceptable ranges for $\mathrm{N}, \mathrm{P}, \mathrm{K}, \mathrm{Ca}, \mathrm{Mg}$, and Na except in 1991 when levels were deficient due to excessive rainfall and leaching. Leaf B levels were similar for all reclaimed wastewater treatments but were lower for the canal water treatment in 1992 and 1993. Fruit growth rate, fruit and juice weight, total soluble solids (TSS), titratable acidity (TA), and TSS : TA ratio were similar for all treatments in 2 of 3 years. Peel thickness was similar for all treatments. Heavy metal concentration in the reclaimed wastewater was at low or nondetectable levels. Similarly, enteric viruses in the effluent were always $<0.003$ plaque forming units/liter. Reclaimed wastewater irrigation significantly increased weed growth compared to the canal water treatment.
\end{abstract}

In Florida, 34\% of water available to agriculture is used to irrigate citrus trees (Smajstrla et al., 1992). Competition for limited water resources is increasing among urban, industrial, and agricultural interests. This competition is especially acute in the coastal areas of Florida where salt water intrusion is often a problem due to excessive demand on the groundwater supply. In addition, urban growth in the coastal areas has increased the need for efficient and environmentally safe disposal of municipal reclaimed wastewater. Currently, about one-half of all citrus in Florida is grown in flatwoods areas of Florida on spodic soils (Florida Dept. of Agriculture and Consumer Services, 1992). The use of reclaimed wastewater for irrigation of citrus is potentially beneficial to urban and agricultural interests. Reclaimed wastewater could provide an economical means of irrigating, decrease pollution of surface waters, and provide groundwater recharge.

Reclaimed wastewater has been used to irrigate citrus for many years (Kale and Bal, 1987; Omran et al., 1988; Zekri and Koo, 1993) and has several potential advantages. Reclaimed wastewater contains many essential nutrients for plant growth and its application may reduce fertilizer application rates (Neilsen et al., 1989). In addition, uptake of plant nutrients in reclaimed wastewater and reduction in fertilizer use may prevent surface water and/or groundwater contamination (Sanderson, 1986). Potential disadvantages of using reclaimed wastewater include accumulation of phytotoxic levels of heavy metals (Omranet al., 1988), high salinity (Basiouny, 1982), and concern over the health risk associated with viruses and bacteria in the water (Brenner et al., 1988; Gleason et al., 1984; Rose and Gerba, 1991).

Received for publication 29 Aug. 1994. Accepted for publication 11 Jan. 1995. University of Florida Journal series no. R-04054. Funding provided by St. Johns River Water Management District and Indian River County, Fla. Thanks to Mike Rinehart for his technical assistance. The cost of publishing this paper was defrayed in part by the payment of page charges. Under postal regulations, this paper therefore must be hereby marked advertisement solely to indicate this fact.
Reclaimed wastewater has been used to irrigate citrus on the deep sandy soils of the Ridge area of Florida (Zekri and Koo, 1993) and is being tested on some spodic soils, but no in-depth studies have been conducted on the eastern coast flatwoods where soil type and drainage patterns are variable due to the presence of hard pans and a high water table. The objective of this study was to evaluate the effects of irrigation with reclaimed wastewater on the growth and development, fruit quality, and yield of mature 'Redblush' grapefruit trees on spodic soils. The seasonal effects of high levels of reclaimed wastewater on soil water content (SWC) were also studied. The overall goal of this study was to determine whether citrus growers can safely and economically use reclaimed wastewater for citrus irrigation on spodic soils in Florida.

\section{Materials and Methods}

The experimental site consisted of an 8. 1-ha block of 25-year old 'Redblush' grapefruit trees (at the beginning of the study) on sour orange rootstock. The study was conducted from 1 Oct. 1990 to 18 Apr. 1994. The site was located adjacent to the Indian River County municipal wastewater treatment facility located near Vero Beach, Fla. Trees were planted on double beds $18.3 \mathrm{~m}$ wide and $177 \mathrm{~m}$ long. The crest of the bed was about $1 \mathrm{~m}$ above the bottom of the water furrows. Trees were spaced $9.15 \mathrm{~m}$ between and $6.1 \mathrm{~m}$ within rows (29 trees/row). The soil type was predominantly a Wabasso fine sand (sandy, siliceous, hyperthermic Alfic Haplaquods) with areas of Chobee loamy fine sand (fine-loamy, siliceous, hyperthermic Typic Argiaquolls) and EauGallie fine sand (sandy, siliceous, hyperthermic Alfic Haplaquods) occurring in portions of the block. The soil had a volumetric field capacity of $9.95 \%$, a permanent wilting point of $2.48 \%$, and a mean bulk density of $1.61 \mathrm{~g} \cdot \mathrm{cm}^{-3}$. Depth to the hardpan varied from $60-120 \mathrm{~cm}$ and rooting depth about $40 \mathrm{~cm}$ from the crest of the bed. Rooting depth varied with seasonal fluctuations in water table depth, which ranged from $30-40 \mathrm{~cm}$. 
Four treatments were arranged in a completely randomized design with each double bed representing a replicate (four replications/treatment). Irrigation treatments were arranged in this manner to ensure statistical validity and because it was impractical to irrigate an area smaller than an entire bed. Treatments consisted of canal water applied based on available soil water depletion of onethird from January-June and two-thirds from July-December (Koo, 1963) and reclaimed wastewater (secondary treated municipal wastewater) applied at $23.1 \mathrm{~mm} /$ week (low), $30.7 \mathrm{~mm} /$ week (moderate) and $38.6 \mathrm{~mm} /$ week (high). Treatments received 2749, 9477, 11,986, and 14,846 kl of water in 1990-91, which included the last 3 months of 1990; 2700, 7650, 10,587, and 12,881 kl of water in 1992 and 2176, 7468,9982, and 12,315 kl of water in 1993 for the canal water, low, moderate and high reclaimed wastewater treatments, respectively. Trees were irrigated using $56.8 \mathrm{liter} \cdot \mathrm{h}^{-1}$, $360^{\circ}$ Maxijet microsprinklers (two/tree) located within the tree row, The wetting pattern was $4.3 \mathrm{~m}$ in diameter at $101 \mathrm{kPa}$ pressure. The arrangement of the microsprinklers overlapped sufficiently to provide coverage of the entire grove floor within the tree rows $(0.086 \mathrm{ha} / \mathrm{bed})$. The drive middles and furrows between tree rows were not irrigated. Trees receiving the low and moderate reclaimed wastewater treatments were irrigated 2 days/week and the high reclaimed wastewater treatment 3 days/week for $24 \mathrm{~h} /$ application except when the water furrows were being cleaned from 25 Nov.16 Dec. 1991.

All treatments received about $135 \mathrm{~kg} \mathrm{~N} / \mathrm{ha}$ per year. The canal water treatment was fertilized two times/year (one-half on $15 \mathrm{Feb}$, 1990, one-half on 15 Aug, 1990) using a 12N-2P-16K analysis granular fertilizer. Since reclaimed wastewater contains N, P, K, and other nutrients (Davies and Maurer, 1993), fertilizer rates were adjusted for these treatments to standardize $\mathrm{N}$ levels among treatments, although $\mathrm{P}$ and $\mathrm{K}$ levels varied yearly. In 1991, granular fertilizer $(10 \mathrm{~N}-2 \mathrm{P}-15 \mathrm{~K})$ was applied on 15 Mar. at 67 , 51,28 , and $0 \mathrm{~kg} \mathrm{~N} / \mathrm{ha}$ for the canal water, low, moderate and high reclaimed wastewater treatments, respectively. The second application was not made in 1991 due to excessive rainfall, which prevented fertilizer spreaders from entering the grove. In 1992, granular fertilizer $(12 \mathrm{~N}-0 \mathrm{P}-0 \mathrm{~K})$ was broadcasting the tree row on 11 Mar. at $67,67,45$, and $23 \mathrm{~kg} \mathrm{~N} / \mathrm{ha}$ for the canal water, low, moderate, and high reclaimed wastewater treatments, respec- tively. A second application of granular fertilizer (10N-0P-15K) was made on 7 July and consisted of $67 \mathrm{~kg} \mathrm{~N} / \mathrm{ha}$ applied to the canal water treatment. The remaining $\mathrm{N}$ was provided in the reclaimed wastewater. In 1993, granular fertilizer $(12 \mathrm{~N}-0 \mathrm{P}-15 \mathrm{~K})$ was applied on $18 \mathrm{Feb}$. at $67,51,28$, and $0 \mathrm{~kg} \mathrm{~N} /$ ha for the canal water, low, moderate, and high reclaimed wastewater treatments, respectively. The second application of granular fertilizer $(12 \mathrm{~N}-2 \mathrm{P}-$ $12 \mathrm{~K}$ ) was made on $30 \mathrm{Aug}$. at $67 \mathrm{~kg} \mathrm{~N} / \mathrm{ha}$ to the canal water treatment. The high reclaimed wastewater treatment received low levels or no granular fertilizer during the study and received from 105 to $129 \mathrm{~kg} \mathrm{~N} / \mathrm{ha}$ per year from the reclaimed wastewater alone depending on the season. Amount of $\mathrm{N}$ applied per year was calculated based on a 0.69 ha treated area per treatment $(0.086$ ha per bed $\mathrm{x}$ four replications/treatment), the amount of water applied, and a nitrate- $\mathrm{N}$ concentration of $5.6 \mathrm{mg} \cdot \mathrm{liter}^{-1}$.

Soil moisture was monitored with a neutron probe (model 4300; Troxler, Raleigh, N. C.) once a week for the reclaimed wastewater treatments and twice a week for the canal water treatment. One aluminum access tube was placed at the drip line about half-way down the tree row of each bed during 1990-92. In 1993, additional tubes were placed at the eastern and western ends of the canal water beds because of variations in SWC along the bed, Soil water content in the canal water treatment was then determined by taking the average of the three lowest readings from the 12 tubes. These tubes were selected so that trees would be irrigated based on the driest soil conditions to ensure that the canal water trees would not be under severe water stress. In some areas, SWC was always at or above one-third soil water depletion. Neutron probe readings were taken at a depth of $23 \mathrm{~cm}$ from the crest of the bed because most of the roots were located in this region.

Growth and development. Tree vigor was rated visually before beginning irrigation treatments in 1989 and each subsequent year. The grove had been irrigated using flooding, but was converted to microsprinkler irrigation in Fall 1989. Visual evaluations were madeon 17 Nov. 1989, 13 Dec. 1990, 11 May 1991, 14 Sept. 1992, and 23 Dec. 1993. Twelve trees/bed were randomly selected as subsamples. Trees were rated from 1 (poorly growing, unhealthy) to 8 (vigorous, healthy). In addition, trunk diameter measurements were taken about $30 \mathrm{~cm}$ above ground level each year from 1990 93.

Table 1. Average chemical analysis of reclaimed wastewater and canal water from Vero Beach, Fla. ${ }^{2}$

\begin{tabular}{|c|c|c|}
\hline & Reclaimed wastewater & Canal water \\
\hline \multicolumn{3}{|l|}{ Characteristic } \\
\hline $\mathrm{pH}$ & $7.07 \pm 0.10$ & $7.46 \pm 0.16$ \\
\hline Electrical conductivity ( $\mu$ mhos) & $764.6 \pm 72.4$ & $1058.0 \pm 211.1$ \\
\hline Ammonium-N & $0.32 \pm 0.41$ & $0.17 \pm 0.16$ \\
\hline Boron & $0.42 \pm 0.04$ & $0.11 \pm 0.01$ \\
\hline Cadmium & $\mathrm{ND}^{\mathrm{y}}$ & ND \\
\hline Copper & $0.003 \pm 0.007$ & $0.009 \pm 0.011$ \\
\hline Lead & $0.001 \pm 0.005$ & $0.002 \pm 0.006$ \\
\hline Magnesium & $13.64 \pm 3.64$ & $27.63 \pm 6.28$ \\
\hline Nickel & ND & ND \\
\hline Nitrate-N & $5.61 \pm 2.20$ & $0.48 \pm 0.52$ \\
\hline Phosphorus & $3.88 \pm 1.24$ & $0.13 \pm 0.08$ \\
\hline
\end{tabular}

${ }^{\overline{2}}$ Values represent the mean of three samples/month collected from October 1992 to November 1993.

${ }^{y} \mathrm{ND}=$ none detected or below detectable limits. 
Fruit growth was determined by randomly selecting and tagging eight fruit/tree (two fruit from each quadrant) from four trees/ bed and measuring the fruit equatorial diameter each month. Measurements were begun on 13 Mar. 1990, 18 Apr. 1991, 14 May 1992, and 11 June 1993 after initial fruit drop. Dates varied seasonally due to differences in bloom date.

Leaf tissue analysis. Leaves for mineral nutrient analysis were collected in August 1990-91 and September 1992-93. In 199091,100 mature spring flush leaves from nonfruiting branches were selected from the 12 sample trees in each bed and four beds/ treatment. In 1992-93, five leaves from four sample trees were collected with three samples/bed and four beds/treatment. This sampling technique permitted us to determine the amount of treeto-tree variation within a bed. Leaves were then processed as described previously (Maurer and Davies, 1993).

Fruit quality. Fruit weight, juice weight, peel thickness, total soluble solids (TSS), titratable acidity (TA), and TSS: TA ratio were measured monthly beginning in August, September, and October 1991, 1992, and 1993, respectively. This starting date varied yearly based on date of full bloom. Fruit samples consisted of 10 fruit/tree (Wardowski et al., 1979) from three trees/bed and four beds/treatment. Fruit were sectioned equatorially so that peel thickness could be measured with a hand caliper and the juice extracted by hand with a Sunkist motor driven extractor. TSS was determined with a temperature-compensating refractometer and TA by titration of a 25$\mathrm{ml}$ aliquot of juice using $0.3125 \mathrm{~N} \mathrm{NaOH}$ to an endpoint with phenolphthalein as an indicator (Wardowski et al., 1979).

Levels of $\mathrm{Cd}, \mathrm{Pb}$, and $\mathrm{Ni}$ were determined by taking 7-mm core samples from the peel of 10 fruit/tree from three trees/bed and four beds/treatment on 15 Oct. 1991 and 6 Jan. 1993. The samples were then dried at 70C for $48 \mathrm{~h}$ and processed as previously described for leaf tissue (Maurer and Davies, 1993).

Yield. Yield was determined from 199 1-94 by counting the number of $405-\mathrm{kg}$ bins harvested/bed and dividing the total by the number of healthy productive treeslbed. Yield was then averaged for four beds (replicates)/treatment. In March 1992, a severe storm caused many fruit to drop before harvest of some of the trees. An estimate of fruit drop was made by counting fruit under sample trees in each bed. Fruit drop averaged $20 \%-25 \%$ of total yield. In addition, each bed was evaluated yearly for missing or severely diseased trees. The healthy tree count per bed was then revised before harvest.

Water quality analysis. Water quality was monitored monthly for the canal water and reclaimed wastewater by collecting samples at the water input source to the irrigation system (Table 1). Three water samples from each source were collected and analyzed for $\mathrm{pH}$, electrical conductivity (EC), $\mathrm{NH}_{4}^{+}, \mathrm{NO}_{3}^{-}, \mathrm{PO}_{4}^{-}, \mathrm{K}, \mathrm{Ca}, \mathrm{Mg}, \mathrm{Zn}$, $\mathrm{Cu}, \mathrm{Cd}, \mathrm{Ni}, \mathrm{Pb}, \mathrm{Na}$, and $\mathrm{B}$. The $\mathrm{pH}$ was determined using a $\mathrm{pH}$ meter (model 520A; Orion Research, Boston) and EC with a conductance meter (model 35; YSI, Yellow Springs, Ohio). Nitrate- $\mathrm{N}$ was determined on the rapid flow analyzer (Alpkem Corp., Clackamas, Ore.). Ammonium-N and $\mathrm{PO}_{4}^{-}$were determined on an

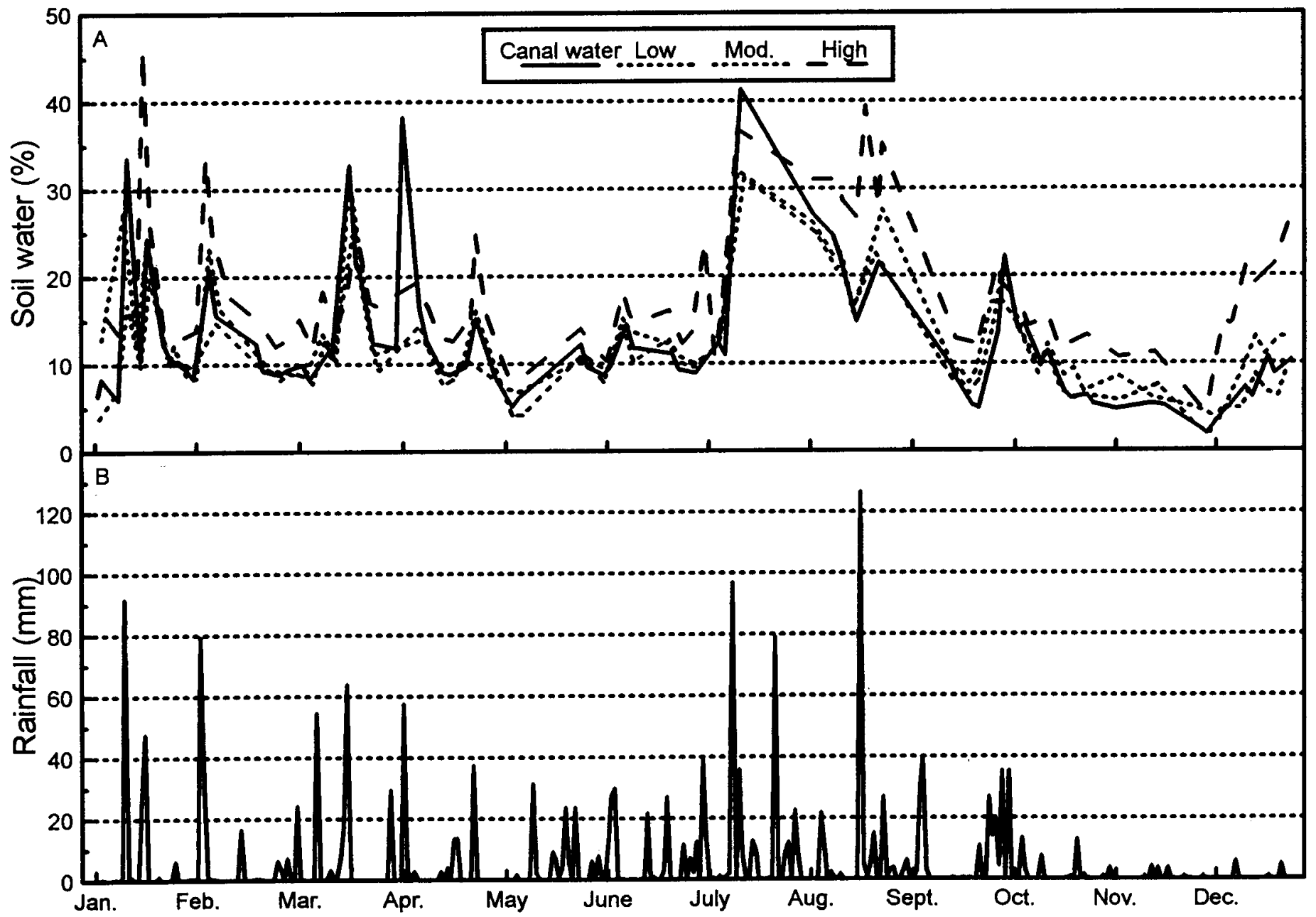

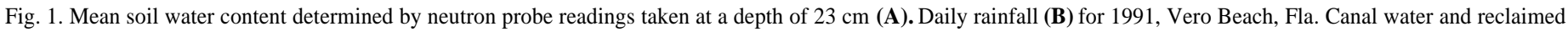
wastewater at low $=23,1 \mathrm{~mm} /$ week, moderate $=30.7 \mathrm{~mm} /$ week, and high $=38,6 \mathrm{~mm} /$ week rates. 
autoanalyzer (AutoAnalyzer II; Technicon Instruments Corp. Tarrytown, N.Y.). All other nutrients were analyzed by the Analytical Research Laboratory, Univ. of Florida, Gainesville, on an inductively coupled argon plasma spectrometer (Thermo Jarrell Ash Corp., Boston).

Analysis of influent and effluent water for enteroviruses was made quarterly. Samples consisted of three 1-liter influent samples collected at the inlet valve where the wastewater entered the treatment facility and three 387-liter effluent samples collected at the efflux valve. Analysis during 1990-91 was conducted by the State of Florida, Dept. of Health and Rehabilitative Services (HRS). Subsequent analysis was performed byS. Farrah at the Dept. of Microbiology and Cell Sciences, Univ. of Florida, Gainesville. Procedures used for analysis of enterovirttses levels were modified from those described in the U.S. EPA Manual of Methods for Virology.

In addition, eight fruit each from the high reclaimed wastewater and canal water treatments were harvested in 17 Mar. 1992 and 18 Feb. 1993 and analyzed for the presence of enteroviruses (S. Farrah, unpublished data). Each grapefruit was placed in a sterile beaker with $200 \mathrm{ml}$ of $0.05 \%$ beef extract at $\mathrm{pH} 9$. After mixing for 5 rein, the solution was removed and concentrated by adjustment to $\mathrm{pH} 3.5$ and addition of $0.005 \mathrm{M}$ ferric chloride to enhance flocculation. Samples were centrifuged at $14,500 \times \mathrm{g}$ for $10 \mathrm{~min}$. The floe was suspended in $10 \mathrm{ml}$ of $0.15 \mathrm{~m}$ sodium phosphate and again centrifuged. The supernatant was adjusted to $\mathrm{pH} 7$ and assayed as described in the U.S. EPA Manual of Methods for Virology. Seeded studies with poliovirus added to the surface of the grapefruit showed that $58 \%$ of the added virus could be recovered in the final sample.

Weed growth. Weed growth within the tree rows was determined monthly by visual evaluation beginning in January 1992. Ratings ranged from 0 (no weed growth) to 5 ( $50 \%$ of ground surface covered with weeds). All beds had bahiagrass groundcover between rows, which was mowed as necessary. Pest, weed and disease control treatments were applied as currently recommended for groves receiving standard irrigation in the Vero Beach area. No adjustments in herbicide or pest control practices were made initially for the reclaimed wastewater treatments. However, after observing the influence of high rates of reclaimed wastewater application on weed growth, some changes in herbicide practices were made, including use of less water-soluble materials and more frequent spot sprays.

Weather data. Weather data were collected using a remote weather station (Campbell Scientific, Logan, Utah). Temperature, relative humidity, solar and quantum radiation, and rainfall data were collected daily.

Statistical analysis. Experiments were analyzed using the SAS general linear model (GLM) procedure and analysis of variance (ANOVA). Visual ratings and trunk diameter values were ana-

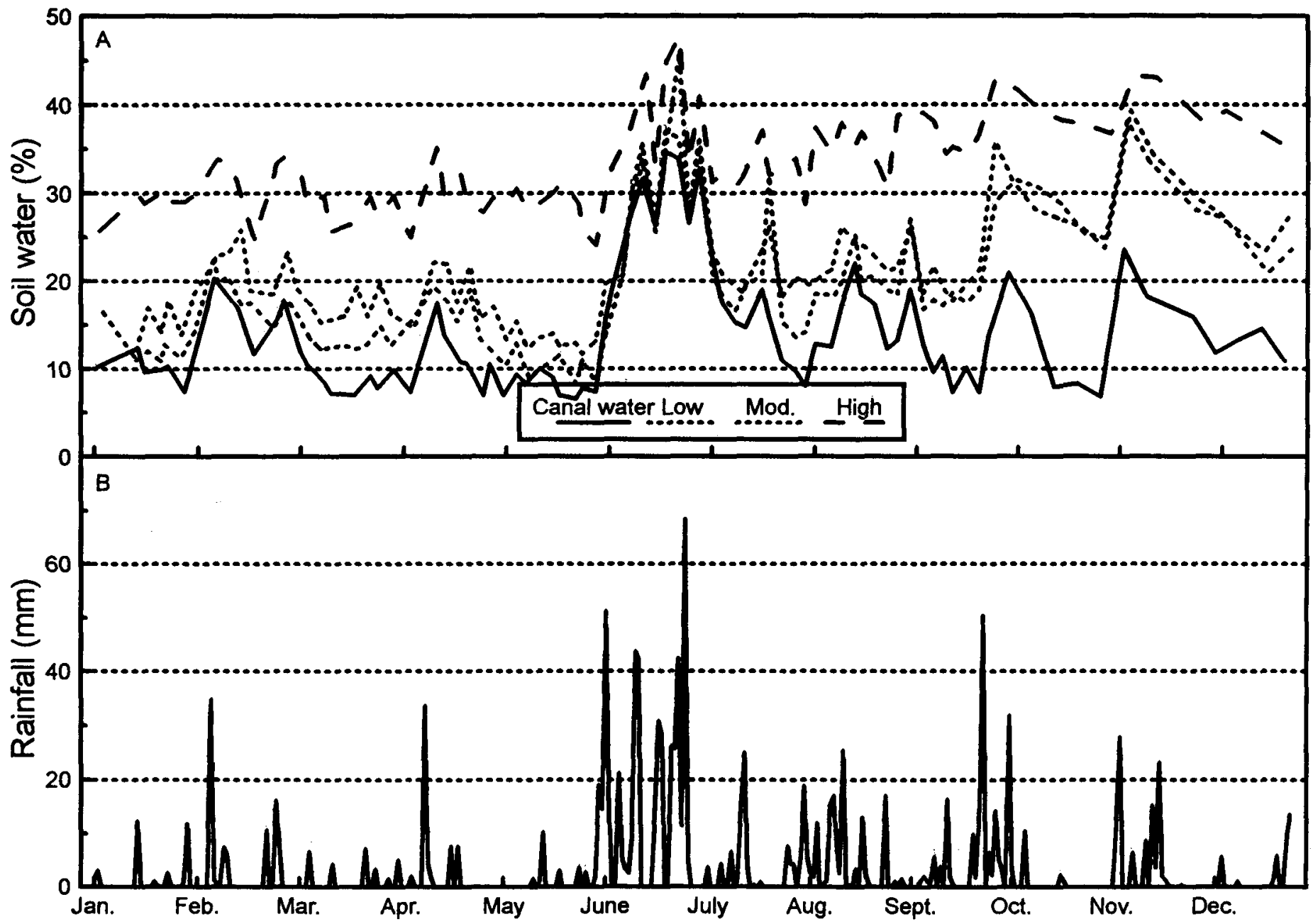

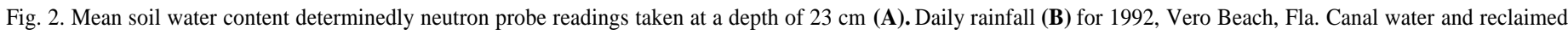
wastewater at low $=23.1 \mathrm{~mm} /$ week, moderate $=30.7 \mathrm{~mm} /$ week, and high $=38.6 \mathrm{~mm} /$ week rates . 
lyzed using analysis of variance. Repeated measures analysis was used in analyzing yields, fruit growth, fruit quality, and weed intensity. Regression analysis was used to determine trends in yield data and contrasts were used to separate means where appropriate.

\section{Results and Discussion}

Soil water content and rainfall. Soil water content and rainfall were monitored from 1991-93 (Figs. 1 -3). In 1991, SWC represented the combined values from this experiment and an adjacent experiment in the northern part of the grove. Although both experiments were conducted on the same soil types differences in drainage patterns and irrigation levels resulted in lower mean SWC levels in 1991 than in subsequent years. Soil water content averaged $12.4 \%, 12.5 \%, 11.6 \%$, and $17.4 \%$ for beds receiving the canal water, low, moderate and high reclaimed wastewater treatments, respectively (Fig, 1) all of which are above field capacity. However, SWC decreased to one-third to two-thirds depletion at several times during the year. The low SWC observed for all beds in November and December 1991 occurred because irrigation was discontinued from 25 Nov. to 16 Dec. to clean and repair the water furrows to improve drainage.

In 1992, SWC data represent measurements from this experiment only. Beds receiving the canal water, low, moderate, and high reclaimed wastewater treatments averaged $13.9 \%, 21.5 \%, 19.5 \%$, and 33.3\% SWC, respectively (Fig. 2). All reclaimed wastewater treated beds had moderate S WC until June 1992, when SWC began to increase due to high rainfall. In 1993 SWC averaged $10.9 \%$, $29.8 \%, 29.8 \%$, and $38.5 \%$ for beds receiving the canal water, low, moderate and high reclaimed wastewater treatments, respectively (Fig. 3). In 1992 and 1993, SWC decreased to less than one-third or two-thirds depletion several times and trees were irrigated.

Soil water content was consistently higher for the reclaimed wastewater treatments compared to those receiving canal water. Beds receiving the low and moderate reclaimed wastewater treatments had similar SWC, which were lower than those in the high reclaimed wastewater treated beds in 1992-93. The difference between beds receiving the low and moderate reclaimed wastewater treatments and the high treatment resulted from more frequent applications at the high rate. The low and moderate reclaimed wastewater treated beds were irrigated twice/week and the high reclaimed wastewater beds three times/week for 2-4 h each. Soil water content measurements were taken before irrigation so that the lowest SWC level was measured. The longer durations between irrigations for the low and moderate reclaimed wastewater treatments allowed for greater soil water depletion. After periods of high rainfall, the canal water beds periodically showed higher SWC than beds receiving reclaimed wastewater. Nevertheless, SWC of the canal water treatments reached one-third to two-thirds depletion at several times during each season but most often during spring and fall.

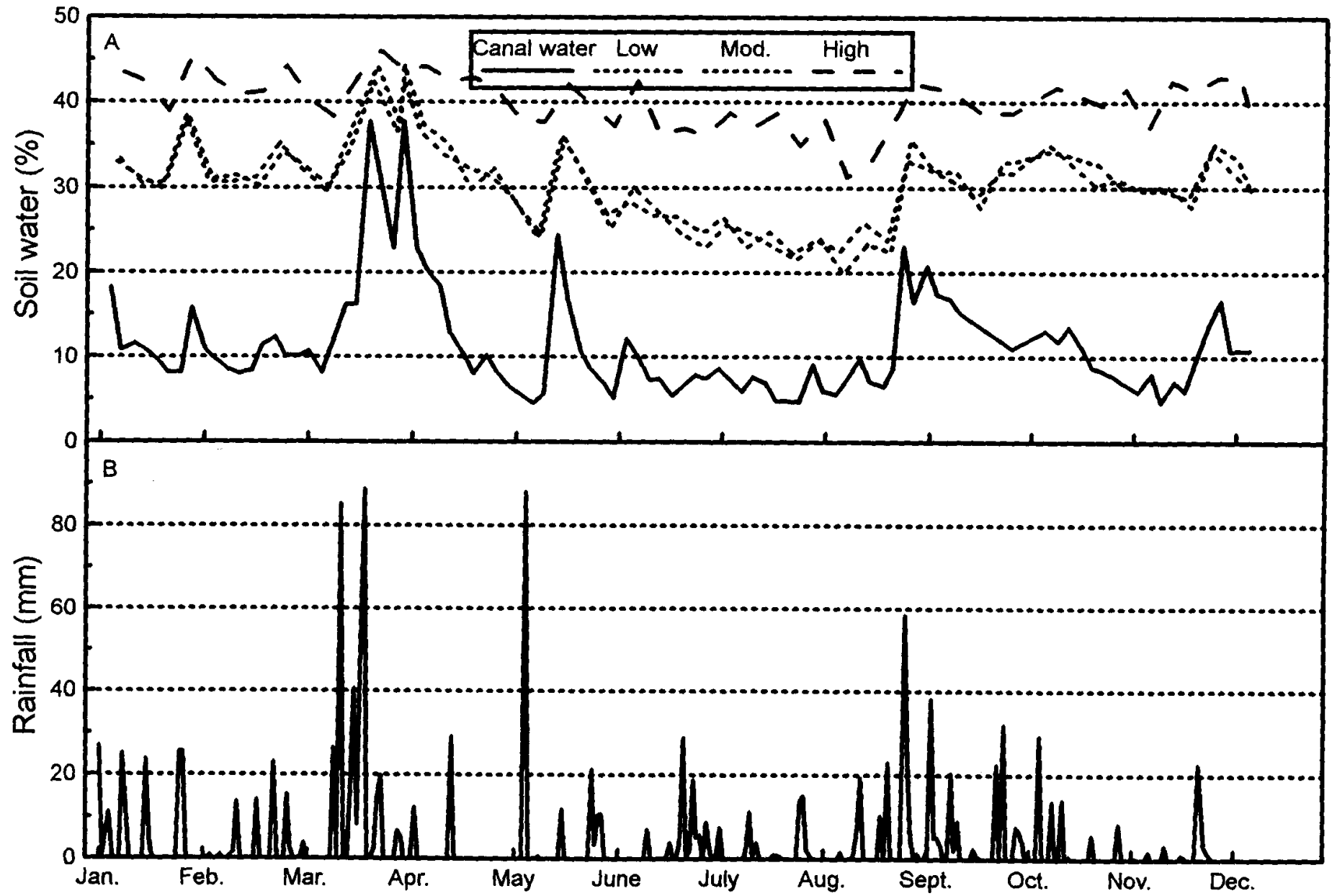

Fig. 3. Mean soil water content determined by neutron probe readings taken at a depth of $23 \mathrm{~cm}$ (A). Daily rainfall (B) for 1993 , Vero Beach, Fla. Canal water and reclaimed wastewater at low $=23.1 \mathrm{~mm} /$ week. moderate $=30.7 \mathrm{~mm} /$ week, and high $=38.6 \mathrm{~mm} /$ week rates . 
Tree growth. Trees receiving moderate reclaimed wastewater were generally more vigorous than those receiving the other treatments; however, in 1992 all reclaimed wastewater treated trees were significantly more vigorous than trees receiving canal water (data not shown). Results are similar to those observed for citrus growing on the Ridge area of Florida (Zekri and Koo, 1993). However, in these previous studies, no adjustment in fertilization rate was made to account for nutrients in the reclaimed wastewater.

Trunk diameter also was similar in 1990-92 for all treatments, ranging from an average of 20.6 to $23.9 \mathrm{~cm}$; however; in 1993, trees receiving low and moderate reclaimed wastewater treatments had significantly greater trunk diameters $(23.8 \mathrm{~cm})$ than those receiving the canal water $(21.8 \mathrm{~cm})$.

Yields. Fruit from the 1990-9 1 season were harvested in October 1990 and again in June 1991. A moderate freeze in December 1989 had caused two blooms to occur one in February 1990 and a second in March-April 1990. Before implementing the irrigation treatments, yields in 1990-91 were statistically similar for all beds, averaging $194 \mathrm{~kg} /$ tree (Table 2). Initially yield data were analyzed by repeated measures analysis and regression within a year to determine optimum irrigation rates. No significant trends emerged because the most significant differences occurred between the canal water and reclaimed wastewater treatments. Thus, contrasts were used to separate means. The 199 1-92 crop was harvested in March 1992. Trees receiving low and moderate reclaimed wastewater treatments produced significantly higher yields than those receiving canal water. Yield for the high reclaimed wastewater trees was also greater than for canal water trees $(P \leq 0.14)$, but was similar to the low and moderate reclaimed wastewater treatments (Table 2). Harvest of the 1992-93 crop began in early March 1993. On 13 Mar. 1993, a severe wind storm caused an estimated loss of $41 \mathrm{~kg} /$ tree for some of the trees. This estimate was added to the yield to adjust for these losses. Yield for the low, moderate and high reclaimed wastewater treatments was significantly greater than for the trees receiving canal water at $P \leq 0.05,0.11$, and 0.10 , respectively (Table 2). The 1993-94 crop was harvested from 1518 Apr. 1994. Yields in all reclaimed wastewater treatments were similar and greater than those for the canal water treatment at $P \leq$ $0.04,0.03$, and 0.11 for the low, moderate, and high rates, respectively (Table 2).

Irrigation during the critical period from bloom through fruit set is important for increasing yields of citrus (Bielorai, 1978; Koo, 1963). The high levels of reclaimed wastewater irrigation and the consistently high SWC without producing anaerobic conditions in the root zone (D. Graetz and F.S. Davies, unpublished data) may have accounted for increases in yield in this study. Koo(1963) and Smajstrla and Koo (1984) also found increased yields when trees were irrigated at levels above the crop requirement. The increase in yields was not economically justified, however. In some instances, reclaimed wastewater is provided free to the grower thus making its use economically feasible. Similar increases in yield from reclaimed wastewater use were observed for citrus in the Ridge area of Florida (Zekri and Koo, 1993). Nevertheless, our data suggest that application rates $>30.7 \mathrm{~mm} /$ week may decrease yields for the soil types used in this study. These studies also suggest that irrigating mature citrus trees atone-third or two-thirds soil water depletion may not be adequate for spodosols on the eastern coast of Florida.

Leaf nutrient concentrations. Leaf tissue $\mathrm{N}$ was similar for all treatments in 1990 (2.6\%) and 1991 (1.8\%). In 1990, leaf $\mathrm{N}$ was in the optimum range $(2.5 \%-2.7 \%)$, whereas in 1991 it was in the deficient range $(<2.2 \%)$ (Koo et al., 1984). These deficient $\mathrm{N}$ levels were attributable to higher than normal rainfall from $\mathrm{Au}-$ gust-October 1991 (Fig. 1), which caused leaching of fertilizer from the root zone. Additionally, the wet soil conditions prevented a second fertilizer application. Boman (1993) observed a similar reduction of leaf $\mathrm{N}$ from excessive rainfall and leaching in $\mathrm{Ft}$. Pierce, Fla. In 1992-93, leaf N concentrations for trees receiving canal water were slightly but significantly higher than those for the reclaimed wastewater treatments (Tables 3-4). In 1993, leaf N concentration was greater for trees receiving the moderate and high reclaimed wastewater treatments than for those receiving the low levels. The differences in leaf $\mathrm{N}$ levels, however, were small and are probably not significant from a practical standpoint. In addition, lower than optimum leaf $\mathrm{N}$ concentrations are desirable for the production of fresh-market grapefruit in the Indian River area (Koo et al., 1984).

Leaf P concentrations were similar for all treatments in 1990 (0.13\%), $1991(0.09 \%)$, and 1992 (Table 3). In 1990-92, leaf P concentrations were in the optimum range $(0.12 \%-0.16 \%)$; however, in 1991, leaf $\mathrm{P}$ was in the low range $(0.09 \%-0.11 \%)$ (Koo et al., 1984), again due to excessive rainfall. Although there were

Table 2. Reclaimed wastewater and canal water effects on yield of 'Redblush' grapefruit trees at Vero Beach, Fla., 1990-94.

\begin{tabular}{|c|c|c|c|c|}
\hline \multirow[b]{2}{*}{ Treatment } & \multicolumn{4}{|c|}{ Yield (kg/tree) } \\
\hline & 1990-91 & 1991-92 & $1992-93$ & 1993-94 \\
\hline \multicolumn{5}{|l|}{ Control } \\
\hline Canal water (CW) & 180 & 147 & 221 & 125 \\
\hline \multicolumn{5}{|l|}{ Reclaimed wastewater } \\
\hline Low, $23.1 \mathrm{~mm} /$ week & 196 & 208 & 317 & 201 \\
\hline Moderate, $30.7 \mathrm{~mm} /$ week & 212 & 221 & 322 & 221 \\
\hline High, 38.6 mm/week & 188 & 188 & 288 & 183 \\
\hline \multicolumn{5}{|l|}{ Significance } \\
\hline Treatment & NS & $*$ & + & $*$ \\
\hline \multicolumn{5}{|l|}{ Contrasts } \\
\hline CW vs. low & NS & $*$ & + & $*$ \\
\hline CW vs. moderate & NS & $*$ & + & $*$ \\
\hline CW vs. high & NS & NS & NS & + \\
\hline Low vs. moderate & NS & NS & NS & NS \\
\hline Low vs. high & NS & NS & NS & NS \\
\hline Moderate vs. high & NS & NS & NS & NS \\
\hline
\end{tabular}

${ }^{2}$ Means of 58 trees/bed and 4 replications/treatment.

Ns $,, *, * * *, * * *$ Nonsignificant or significant at $P \leq 0.10,0.05,0.01$, or 0.001 , respectively. 
statistically significant differences in leaf $\mathrm{P}$ among treatments in 1993, levels were within the optimum range (Table 4). Increases in leaf $\mathrm{P}$ are often associated with reclaimed wastewater irrigation in citrus (Zekri and Koo, 1993). The low levels of P in the reclaimed wastewater and adjustments in $\mathrm{P}$ fertilizer rates could account for a lack of difference among treatments in this study.

Leaf $\mathrm{K}$ concentrations were also similar for all treatments in $1990(0.8 \%), 1991$ ((0.8\%), and 1992 (Table 3). In 1990-92, leaf $\mathrm{K}$ was in the low range $(0.7 \%-1.1 \%)$ (Koo et al., 1984). Leaf K concentration was significantly higher for all reclaimed wastewater treatments than for the canal water treatment in 1993 (Table 4). Although the reclaimed wastewater contained about twice the level of $\mathrm{K}$ as the canal water, statistical differences in leaf $\mathrm{K}$ concentrations did not occur until 1993. However, adjustments in $\mathrm{K}$ fertilization rates attempted to regulate $\mathrm{K}$ levels so that all treatments received similar amounts of $\mathrm{K}$ from either fertilization and/or reclaimed wastewater.

Leaf $\mathrm{Ca}$ and $\mathrm{Mg}$ concentrations were similar for all treatments for all 4 years and were at or above optimum levels (data not shown).

High levels of $\mathrm{B}$ and $\mathrm{Na}$ in the reclaimed wastewater were of concern initially. Leaf B concentrations were not analyzed in 1990, but in 1991 all treatments had similar leaf B concentrations, which were in the low end of the high range (10 1-200 $\mu \mathrm{g} \cdot \mathrm{g}^{-1}$ ) (Koo et al., 1984). Trees irrigated with reclaimed wastewater showed a $50 \%$ increase in leaf B over the canal water treatments in 1992 (Table 3) and all leaf B levels were in the high range. In 1993, trees receiving reclaimed wastewater had twice the concentration of leaf $B$ than those receiving canal water (Table 4 ). Irrigation at the moderate reclaimed wastewater rate increased leaf $\mathrm{B}$ concentrations more than at the other two reclaimed wastewater rates. Leaf B levels for the reclaimed wastewater treatments were within the high range. Reclaimed wastewater contained four times more B than the canal water, which accounts for increased leaf B concentrations. Nevertheless, leaf B concentrations were below toxic levels $\left(>250 \mu \mathrm{g} \cdot \mathrm{g}^{-1}\right)$ for citrus trees (Koo et al., 1984). Increases in leaf B due to reclaimed wastewater treatment is consistent with previous results on citrus (Zekri and Koo, 1993). Leaf Na concentrations were similar for all treatments in all 4 years but were lowest in 1991 due to leaching of $\mathrm{Na}$ beyond the root zone by excessive rainfall.
Levels of $\mathrm{Cu}, \mathrm{Fe}, \mathrm{Mn}$, and $\mathrm{Zn}$ varied yearly but were generally within acceptable ranges. Variations in these micronutrients were more a function of nutritional spray applications than levels in the reclaimed wastewater.

The accumulation of some nutrients in leaf tissue reflect the levels received from the reclaimed wastewater, canal water, or supplemental fertilization. Standardization of N, P, and K levels in the fertilizer resulted in similar leaf nutrient concentrations across treatments. The results obtained here may not be comparable to those of other experiments, where fertilizer rates were not controlled (Zekri and Koo, 1993). In addition, the short duration of this experiment may not account for long-term accumulation of nutrients with continued reclaimed wastewater use. Omran et al. ( 1988) found that leaf nutrient levels of citrus tended to increase with increasing duration of reclaimed wastewater use.

Fruit growth, weight, and juice weight. Fruit growth patterns were similar in 1990-92, (data not shown) for all treatments and followed a typical sigmoid growth pattern for citrus fruit (Bain, 1958). The lack of difference in fruit growth in 1991 may have been attributed to above normal rainfall during the summer. In contrast, in 1993 trees receiving reclaimed wastewater had significantly larger fruit than those receiving canal water, averaging 95 and 90 $\mathrm{mm}$ in diameter at the end of the season, respective $\mathrm{y}$.

Fruit weight for trees receiving reclaimed wastewater treatments was significantly greater than for those receiving canal water in 199 1-92 (data not shown). Fruit and juice weight were generally greater for trees receiving reclaimed wastewater than for fruit from canal water treatments in all three seasons, although some tree-to-tree variability occurred (data not shown). There were no differences in weight or juice content among reclaimed wastewater treatments. Peel thickness was similar for all treatments in each of the 3 years.

Fruit quality. TSS was significantly lower for trees receiving moderate reclaimed wastewater compared with the other treatments in 199 1-92 and 1993-94; however, differences were very small. In 1992-93, fruit had similar TSS for all treatments. The variable effects of high irrigation levels on TSS are consistent with results obtained in other studies with citrus (Boman, 1992; Zekri and Koo, 1993).

Juice TA levels were similar for all treatments in 199 1-92 and

Table 3. Reclaimed wastewater and canal water effects on leaf tissue nutrient concentration of 'Redblush' grapefruit trees in Vero Beach, Fla., 1992.

\begin{tabular}{|c|c|c|c|c|c|}
\hline \multirow[b]{2}{*}{ Treatment } & $\mathrm{N}$ & $\mathrm{P}$ & $\mathrm{K}$ & $\mathrm{Na}$ & B \\
\hline & \multicolumn{3}{|c|}{ (\% dry wt) } & \multicolumn{2}{|c|}{$\left(\mu \mathrm{g} \cdot \mathrm{g}^{-1}\right.$ dry $\left.w \mathrm{t}\right)$} \\
\hline \multicolumn{6}{|l|}{ Control } \\
\hline Canal water $(\mathrm{CW})$ & 2.5 & 0.14 & 1.1 & 1284 & 103 \\
\hline \multicolumn{6}{|l|}{ Reclaimed } \\
\hline Low, $23.1 \mathrm{~mm} /$ week & 2.4 & 0.14 & 1.0 & 1129 & 158 \\
\hline Moderate, $30.7 \mathrm{~mm} /$ week & 2.4 & 0.14 & 1.0 & 830 & 179 \\
\hline High, 38.6 mm/week & 2.3 & 0.14 & 1.2 & 1110 & 152 \\
\hline \multicolumn{6}{|l|}{ Significance } \\
\hline Treatment & $*$ & NS & NS & NS & $* * *$ \\
\hline \multicolumn{6}{|l|}{ Contrasts $^{y}$} \\
\hline CW vs. low & $*$ & NS & NS & NS & $* *$ \\
\hline CW vs. moderate & $* *$ & NS & NS & NS & $* * *$ \\
\hline CW vs. high & $* *$ & NS & NS & NS & $* *$ \\
\hline Low vs. moderate & NS & NS & NS & NS & NS \\
\hline Moderate vs. high & NS & NS & NS & NS & NS \\
\hline
\end{tabular}

'Means of 5 leaves/tree from 12 trees/bed and 4 beds/treatment. Leaf samples were taken from fully expanded spring flush leaves on nonfruiting branches in August 1992.

${ }^{y}$ Only significant contrasts are presented.

"s,,$* * * * *$ Nonsignificant or significant at $P \leq 0.05,0.01$, or 0.001 , respectively. 
Table 4. Reclaimed wastewater and canal water effects on leaf tissue nutrient concentration of 'Redblush' grapefruit trees in Vero Beach, Fla., $1993 .{ }^{2}$

\begin{tabular}{|c|c|c|c|c|c|}
\hline \multirow[b]{2}{*}{ Treatment } & $\mathrm{N}$ & $\mathrm{P}$ & K & $\mathrm{Na}$ & B \\
\hline & \multicolumn{3}{|c|}{ (\% dry wt) } & \multicolumn{2}{|c|}{$\left(\mu \mathrm{g} \cdot \mathrm{g}^{-1}\right.$ dry $\left.w \mathrm{t}\right)$} \\
\hline \multicolumn{6}{|l|}{ Control } \\
\hline Canal water $(\mathrm{CW})$ & 2.5 & 0.13 & 1.0 & 1027 & 64 \\
\hline \multicolumn{6}{|l|}{ Reclaimed } \\
\hline Low, $23.1 \mathrm{~mm} /$ week & 2.3 & 0.12 & 1.2 & 1126 & 139 \\
\hline Moderate, $30.7 \mathrm{~mm} /$ week & 2.4 & 0.12 & 1.2 & 1188 & 161 \\
\hline High, $38.6 \mathrm{~mm} /$ week & 2.4 & 0.14 & 1.3 & 1203 & 149 \\
\hline \multicolumn{6}{|l|}{ Significance } \\
\hline Treatment & $* * *$ & $* * *$ & $* * *$ & NS & $* * *$ \\
\hline \multicolumn{6}{|l|}{ Contrasts } \\
\hline CW vs. low & $* * *$ & $*$ & $* *$ & NS & $* * *$ \\
\hline $\mathrm{CW}$ vs. moderate & * & NS & $* * *$ & NS & $* * *$ \\
\hline CW vs. high & $* *$ & NS & $* * *$ & NS & $* * *$ \\
\hline Low vs. moderate & $*$ & NS & NS & NS & $* * *$ \\
\hline Low vs. high & NS & $* * *$ & NS & NS & NS \\
\hline Moderate vs. high & NS & $* *$ & NS & NS & $*$ \\
\hline
\end{tabular}

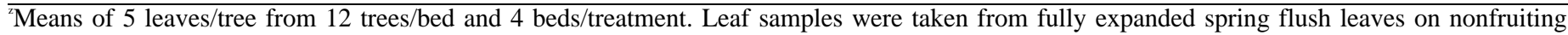
branches in August 1993.

Ns,$* * * * * *$ Nonsignificant or significant at $P \leq 0.05,0.01$, or 0.001 , respectively.

1993-94, but in 1992-93 TA of trees receiving the canal water was significantly higher than for those receiving the reclaimed wastewater treatments: $1.2 \%$ vs $1.0 \%$. Koo (1985) also found that fruit TA was diluted in 1 of 4 years, but Graser and Allen (1987) observed no consistent dilution in fruit TA associated with irrigation. High rates of reclaimed wastewater did not consistently dilute fruit TA in this study. In contrast, fruit TA was consistently lower for trees receiving reclaimed wastewater than well water in the Ridge area of Florida. Irrigation rates were also greater in their study than in ours (Zekri and Koo, 1993).

Fruit TSS : TA ratio was similar for all treatments in 1991-92 and 1993-94. In 1992-93, fruit from the low and moderate reclaimed wastewater treatments had a significantly higher TSS : TA ratio than those from the canal water treatment. This difference occurred from December until harvest and was due to the decrease in fruit TA. Therefore, irrigation had a tendency to increase fruit TSS : TA ratios. Zekri and Koo ( 1993) also observed increases in fruit TSS : TA ratios in 4 of 6 years when using high application of reclaimed wastewater.

Reclaimed wastewater irrigation had inconsistent effects on fruit TSS, TA, and TSS: TA ratio. Use of reclaimed wastewater for irrigation, however, may actually be beneficial. Even though reclaimed wastewater treatments at times caused dilution of fruit TSS and TA, the fruit TSS : TA ratios were actually higher for fruit from the reclaimed wastewater than the canal water treatment as seen in 1992-93. This fruit attained minimum maturity standards about 2 to 3 weeks earlier for reclaimed wastewater vs. canal water treatments.

Heavy metals in fruit. No accumulation of $\mathrm{Cd}, \mathrm{Ni}$, or $\mathrm{Pb}$ occurred in the fruit in 1992-1993. This finding is not surprising, since the reclaimed wastewater had only nondetectable or trace amounts of heavy metals which is typical of nonindustrial wastewater (Table 1). Therefore, use of reclaimed wastewater of this quality poses no threat to citrus trees or consumers from heavy metal accumulation.

Enteric viruses. An important concern related to the use of reclaimed wastewater is the potential health hazards posed by bacteria and viruses in the water. The water used in this project received secondary treatment and chlorination. Reclaimed wastewater analysis for enteroviruses averaged 195.5 plaque forming units (PFU)/liter for the influent, but $<0.003 \mathrm{PFU} /$ liter for the effluent that was used for irrigation. Influent levels varied greatly depending on the season and ranged from 2 1.3-625.0 PFU/liter, but levels in the effluent were consistently low. Furthermore, fruit from trees treated with high rates of reclaimed wastewater also had $<0.003 \mathrm{PFU} /$ liter on the peel. Similar findings were made by the Florida State Dept. of Health (unpublished data). Citrus fruit dipped directly into nontreated wastewater had no enteric viruses in the fruit or on the peel following washing with standard packinghouse procedures. Moreover, the reclaimed wastewater in this study was applied under tree to the soil and not directly to the fruit surfaces. Therefore, any risk to workers or consumers associated with use of reclaimed wastewater is extremely small. Fecal coliform levels were consistently less than levels set by the Florida State Dept. of Health (data not shown).

Weed growth. Weed growth in 1992-93 varied seasonally and with herbicide treatments. Weed growth was nearly always greater for beds receiving reclaimed wastewater (3.5 rating) than canal water (1.0 rating). Increased weed growth has also been associated with use of reclaimed wastewater for irrigation on the Ridge area of Florida (Zekri and Koo, 1993). Application of high amounts of reclaimed wastewater provides abundant water and nutrients for weed growth. In addition, application of high amounts of reclaimed wastewater may leach herbicides from the soil. Weed growth, especially around microsprinklers, also interferes with water distribution and ground coverage (Smajstrla and Koo, 1984).

\section{Conclusions}

Trees receiving reclaimed wastewater tended to be more vigorous and produced higher yields than those receiving canal water based on recommended soil water depletion levels. More importantly, fertilizer rates could be lowered significantly without reducing yields or affecting leaf nutrient levels when using reclaimed wastewater. Fruit growth and quality from trees receiving reclaimed wastewater varied from year to year with no clear trends apparent. Increased weed growth from use of reclaimed wastewater is a major concern and may require changes in weed management practices such as the use of herbicides with low volubility. Increased cost for weed management should be compensated for 
by reductions in fertilizer use and increased yields. Irrigation of mature 'Redblush' grapefruit trees using reclaimed wastewater on the spodic soils studied here did not cause an accumulation of $\mathrm{Na}$, $\mathrm{B}$, or heavy metals. In addition, levels of enteroviruses in the water were extremely small.

Results obtained in this study are applicable to the soil types tested, viz., Wabasso fine sand. Although a hardpan was present at about $60 \mathrm{~cm}$, the upper sandy layer had a very high percolation rate and drained rapidly. In areas of the grove where drainage was impeded due to weed buildup or clogging of drainage pipes, trees became stunted and unproductive. Moreover, irrigation rates should be less than $30.7 \mathrm{~mm} /$ week and irrigation frequency should be two to three times/week. It is important to choose groves that are well designed without low spots to facilitate maximum drainage. Under these conditions, reclaimed wastewater has the potential to increase yields while saving on fertilizer and irrigation costs.

\section{Literature Cited}

Bain, J.M. 1958. Morphological, anatomical, and physiological changes in the developing fruit of the Valencia orange, Citrus sinensis (L.) Osbeck. Austral. J. Bet. 6:1-24.

Basiouny, F.M. 1982. Wastewater irrigation of fruit trees. BioCycle 23(2):51-53.

Bielorai, H. 1978. The prospects of water management for optimum citrus growth and production. Proc. Intl. Soc. Citricult. 2:227-233.

Boman, B.J. 1992. Effects of soil moisture depletion levels on navel oranges on microirrigated flatwoods. Proc. Fla, State Hort. Soc. 105:66-70,

Boman, B.J. 1993. A comparison of controlled-release to conventional fertilizer on mature 'Marsh' grapefruit. Proc. Fla. State Hort. Soc. 106:14.

Brenner, K. P., P.V. Scarpino, and C.S. Clark. 1988. Animal viruses, coliphages, and bacteria in aerosols and wastewater at a spray irrigation site. Applied Environ. Microbiol. 54(2):409-415.

Davies, F.S. and M.A. Maurer. 1993. Reclaimed wastewater for irrigation of citrus in Florida. HortTechnology 3: 163-167.

Embleton, T. W., W.W. Jones, C.K. Labanauskas, and W. Reuther. 1973. Leaf analysis as a diagnostic tool and guide to fertilization, p, 184-210. In: W. Reuther (ed.). Citrus industry. vol. 3. Univ. of Calif. Press. Berkeley.
Florida Department of Agriculture and Consumer Services. 1992. Commercial citrus inventory 1992. Florida Agr. Stat., Orlando.

Gleason, III. T. L., J.E. Smith, Jr., and A.L. Page. 1984. Utilization of municipal wastewater and sludge on land. BioCycle 3:26-30.

Graser, E.A. and L.H. Allen, Jr. 1987. Water management for citrus production in the Florida flatwoods. Proc. Fla. State Hort. Soc. 100:126136.

Kale, C.K. and A.S. Bal. 1987. Reuse of stabilization pond effluent for Citrus reticulata (orange), forest and road verge plants. Water Sci. Technol. 19(12):307-315.

Koo, R.C.J. 1963. Effects of frequency of irrigation on yield of orange and grapefruit. Proc. Fla. State Hort. Soc. 76:1-5.

Koo, R.C.J. 1985. Response of 'Marsh' grapefruit tree to drip, under tree spray and sprinkler irrigation. Proc. Fla. State Hort. Soc. 98:29-32.

Koo, R. C. J., C.A. Anderson, I. Stewart, D.P.H. Tucker, D.V. Calvert, and H.K. Wutscher. 1984. Recommended fertilizers and nutritional sprays for citrus.' Univ. of Fla. Fla. Agr. Expt. Sta. Bul. 536D.

Maurer, M.A. and F.S. Davies. 1993, Microsprinkler irrigation of young 'Redblush' grapefruit trees using reclaimed wastewater. HortScience 28:1157-1161.

Neilsen, G. H., D.S. Stevenson, J.J. Fitzpatrick, and C.H. Brownlee. 1989. Nutrition and yield of young apple trees irrigated with municipal waste water. J. Amer. Soc. Hort. Sci. 1 14:377-383.

Omran, M. S., T.M. Waly, E.M. Abd Elnaim, and B.M.B. El Nashar. 1988. Effect of sewage irrigation on yield tree components and heavy metals accumulation in Navel orange trees. Biol. Wastes 23: 17-24.

Rose, J.B. and C.P. Gerba. 1991. Assessing potential health risk from viruses and parasites in reclaimed water in Arizona and Florida, USA. Water Sci. Technol. 23:2091-2098.

Sanderson, K.C. 1986. Introduction to the workshop on wastewater utilization in horticulture. HortScience 21:23-24.

Smajstrla, A.G. and R.C.J. Koo. 1984. Effects of trickle irrigation methods and amount of water applied on citrus yields. Proc. Fla. State Hort. Soc. 97:3-7.

Smajstrla, A. G., D.S. Harrison, P.Z. Haman, and F.S. Zazuata. 1992. Irrigated acreage in Florida. Fla. Coop. Ext. Serv. Cir. 1030, Univ. of Fla. Press, Gainesville.

Wardowski, W., J, Soule, W. Grierson, and G. Westbrook. 1979. Florida citrus quality test. Univ. of Fla., Coop, Ext. Serv. Bul. 188.

Zekri, M. and R.C.J. Koo. 1993. A reclaimed water citrus irrigation project. Proc. Fla. State Hort. Soc. 106:30-35. 